\title{
A Case of Lipoma in the Middle Ear
}

\author{
Song I Park, Min Hae Park, Jungmin Ahn, and Won Ho Chung \\ Department of Otorhinolaryngology-Head and Neck Surgery, Samsung Medical Center, Sungkyunkwan University School of Medicine, \\ Seoul, Korea
}

\section{중이강에 발생한 지방종 1 예}

박송이 · 박민혜 · 안정민 · 정원호

성균관대학교 의과대학 삼성서울병원 이비인후과학교실

Received April 20,2018

Revised June 2, 2018

Accepted August 17, 2018

Address for correspondence

Won Ho Chung, MD, PhD

Department of Otorhinolaryngology-

Head and Neck Surgery, Samsung

Medical Center, Sungkyunkwan

University School of Medicine,

81 Irwon-ro, Gangnam-gu,

Seoul 06351, Korea

Tel $+82-2-3410-3579$

Fax $+82-2-3410-6987$

E-mail whchung12@gmail.com
Lipoma is a common benign tumor found at various sites in the body, but it is rarely encountered in the middle ear. We report a case of a 5-month-old girl who presented a middle ear lipoma, which was successfully removed by canal wall up mastoidectomy. To the best our knowledge, this is the youngest case of rare middle ear lipoma, which has ever been reported in the literature. Korean J Otorhinolaryngol-Head Neck Surg 2019;62(7):404-8

\section{서 론}

지방종은 발생학적으로 간엽조직으로부터 기원하는 지방 조직으로 구성된 양성 종양으로 보통 얇은 피막에 둘러싸여 있다. 다엽성 혹은 둥근 형태의 낭성 모양을 띠며 주로 단일 병변으로 나타나나 드물게 Madelung's disease처럼 전신질 환의 형태로 다발성으로 나타나는 경우도 있다. ${ }^{1)}$ 일반적으로 몸통 및 경부에 생기며 몸의 어느 부분에라도 발생 가능하 나, 중이강 내에 지방종이 발생한 경우는 거의 보고된 바가 없다.

저자 등이 확인한 바에 의하면 지금까지 소개된 중이강 내 지방종 증례는 총 9건으로 Table 1에 정리하였다. 연령대는 16 개월부터 64 세 성인까지 다양하였으며, 소아에서는 주로 삼 출성 중이염과 청력 소실을 증상으로 발견된 경우가 많았고,

This is an Open Access article distributed under the terms of the Creative Commons Attribution Non-Commercial License (https://creativecommons.org/licenses/by-nc/4.0) which permits unrestricted non-commercial use, distribution, and reproduction in any medium, provided the original work is properly cited.
성인에서는 호흡곤란이나 안면마비 증상으로 발견된 경우가 있었다. 모든 증례에서 중이 수술을 통해 종양의 적출이 가 능하였으며, 경우에 따라 비인강을 통해서 제거하거나, ${ }^{2)}$ 중이 강 내에서 분할 조직 생검으로 일부 제거한 경우 ${ }^{3)}$ 도 있었다.

본 증례는 지속되는 삼출성 중이염을 주소로 내원한 생후 5 개월 여자 환아에서 중이강과 이관 내를 채우고 있는 종괴 를 외이도 후벽보존 유양동절제술 및 확장 고실 개방술로 성 공적으로 제거하여 조직검사상 지방종으로 확인된 증례를 문헌 고찰과 함께 보고하고자 한다.

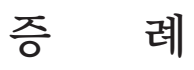

생후 5개월 여자 환아가 생후 2개월부터 발생된 반복되는 삼출성 중이염을 주소로 내원하였다. 검진 상 양측 고막에 팽 륜 및 삼출액 소견을 보였으며, 3개월 후 좌측은 정상 고막 소견으로 호전되었으나 우측은 고막 내측으로 백색 종물이 관찰되었다(Fig. 1). 청력은 청성뇌간유발반응검사상 좌측 
Table 1. List of publications about middle ear lipoma

\begin{tabular}{|c|c|c|c|c|}
\hline Age & Sex & Chief complaint & Treatment & Reference \\
\hline $16 \mathrm{~m}$ & Female & Hearing loss & Mass removal with ossiculoplasty & Karas, et al. ${ }^{11)}$ \\
\hline $25 \mathrm{~m}$ & Female & Middle ear effusion & Tympanoplasty & Chun, et al. ${ }^{12)}$ \\
\hline $2 y$ & Male & Middle ear effusion & Tympanoplasty & Tachibana, et al. ${ }^{5)}$ \\
\hline $4 y$ & Female & Hearing loss & Tympanoplasty & Selesnick, et al. ${ }^{13)}$ \\
\hline $5 y$ & Male & Middle ear effusion & Extended myringotomy with multiple piecemeal biopsy & Abdullah, et al. ${ }^{3)}$ \\
\hline $6 y$ & Male & Hearing loss & Mass removal with ossiculoplasty & Aldosari ${ }^{14)}$ \\
\hline $7 y$ & Female & Middle ear effusion & Tympanomastoidectomy & Edmonds, et al. ${ }^{4)}$ \\
\hline 33 y & Male & Facial nerve palsy & Tympanoplasty & Kasbekar, et al. ${ }^{15)}$ \\
\hline $64 \mathrm{y}$ & Female & Dyspnea, dysphagia & Tympanoplasty, Nasopharyngeal polyp removal & Stegehuis, et al. ${ }^{2}$ \\
\hline
\end{tabular}

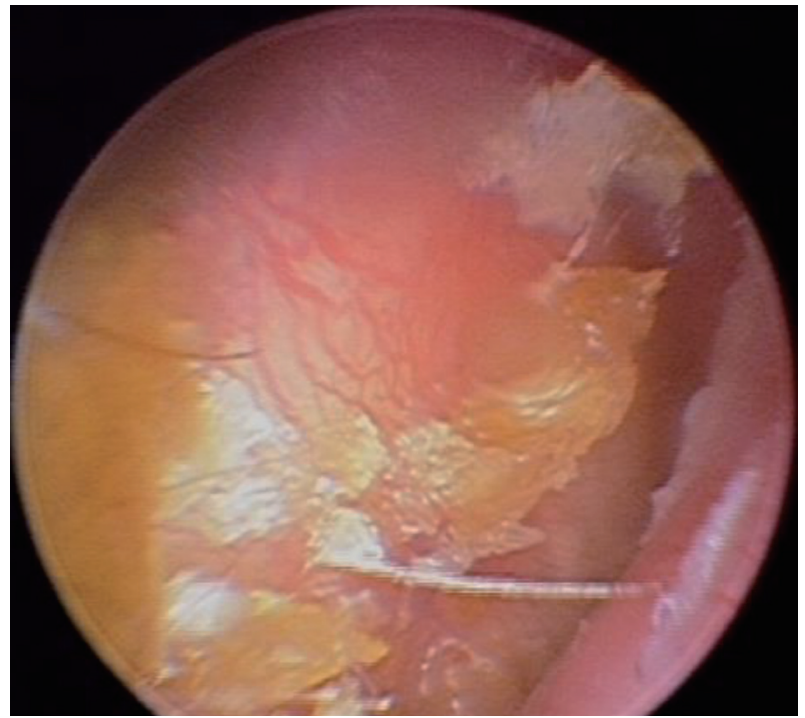

Fig. 1. Endoscopic examination revealed a whitish mass showing through the tympanic membrane.

$25 \mathrm{dBnHL}$, 우측 $60 \mathrm{dBnHL}$ 이었다.

선천성 진주종 의심하에 측두골 전산화단층촬영을 시행 하였으며, 우측 이관을 따라 인접 뼈 구조를 변형시키고 있 는 약 $2 \mathrm{~cm}$ 크기의 저음영 종물이 중이에서부터 부인두강에 걸쳐 관찰되었다(Fig. $2 \mathrm{~A}$ and $\mathrm{B}$ ). 중이강과 유양동 내에 연 부조직 음영이 동반되어 있었으나 주변 골조직의 미란 및 내 이의 파괴 소견은 보이지 않았고, 이소골의 구조적 이상 및 안 면 신경의 노출 등도 없었다. 내이도 자기공명영상 검사상 $\mathrm{T} 1$ 에서 종물은 지방조직과 같은 신호강도를 보였다(Fig. 2C).

중이강 및 부인두강에 위치한 종물을 제거하기 위해 전신 마취하에 고실유양돌기절제술(tympanomastoidectomy)을 시행하였다. 고막은 중이 내의 종물에 의해서 외측으로 팽륜 된 상태였으며, 고실 외이도 피판을 올리자 고막 내측으로 케 라틴 및 화농성 분비물이 관찰되었다. 종물을 광범위하게 노 출시키기 위해 외이도후벽보존 유양동절제술 및 확장 고실 개방술을 시행하였으며, 추골병 전방, 등골 전방 및 침등골
관절과 맞닿아 있는 백색의 타원형 종물이 이관구쪽으로 확 장된 소견이 확인되었다. 중이강 내 점막은 염증성 변화로 인 해 두꺼워진 상태로 일부 제거하였으며, 수술 시 안면신경관 의 결손 및 노출은 없었고 동결절편검사상 악성 소견은 보이 지 않았다. 종양 절제를 위해 침골을 제거한 뒤 중이강 내의 종양을 이소골로부터 분리시켜 외이도를 통해 제거하였으며, 부인두강으로 확장된 남은 종양은 이관으로 빠져나가 비인 두부에서 제거하였다. 종양의 크기는 $3.5 \times 2.3 \mathrm{~cm}$ 였으며, 현 미경 소견상 성숙한 지방세포로 구성되어 지방종에 합당한 소견이었다(Fig. 3).

수술 후 2일째 내이도 자기공명영상 검사를 통해 지방종 이 모두 제거되었음을 확인하였으며(Fig. 4), 수술 후 7개월까 지 환아는 특별한 합병증 없이 외래 진료 통한 경과관찰 중 으로, 추후 청력에 대한 재평가 시행 후 청력 재건술에 대해 고려 예정이다.

\section{고 찰}

중이 및 이관에 발생하는 지방종은 매우 드문 질환으로서 본 증례에 소개된 5개월 환아의 예는 현재까지 보고된 문헌 중 가장 어린 연령의 경우로 생각된다. 영·유아에서 중이에 종 양이 의심될 때 감별해야 할 질환으로는 선천성 혹은 후천성 진주종, 콜레스테롤 육아종, 염증성 용종, 안면신경종, 횡문근 육종, 육종, 혈관육종 및 중이강 내 지방종, 기형종 등이 있 다. ${ }^{4)}$ 일반적으로 소아에서 중이 내에 백색의 종물 소견이 보 일 시 선천성 진주종을 먼저 생각해볼 수 있으나 본 증례에서 다룬 지방종과 같이 드물게 발생하는 다른 질환에 대한 감별 이 필요할 수 있어 이에 대해 문헌을 통해 고찰해보고자 한다.

삼출성 중이염은 영·유아에서 가장 흔한 중이 질환이지 만, 이로 인해 중이 내에 발생한 종양의 발견이 늦어지는 경 우가 종종 있다. 삼출성 중이염이나 전도성 난청은 지방종 자 체에 의한 종괴 효과 및 비인두강 내의 음압으로 인해 지방 
Fig. 2. Pre-operative $C T / M R I$ images. Axial (A) and coronal (B) pre-operative coronal pre-operative temporal bone CT images demonstrating a fat-containing mass located from right tympanic cavity to parapharyngeal space. The mass causes remodeling of nearby bony structure. Pre-operative internal auditory canal MRI T1 image which shows a $2 \mathrm{~cm}$ mass with fat signal intensity occupying right eustachian tube and extending to epitympanum (C).
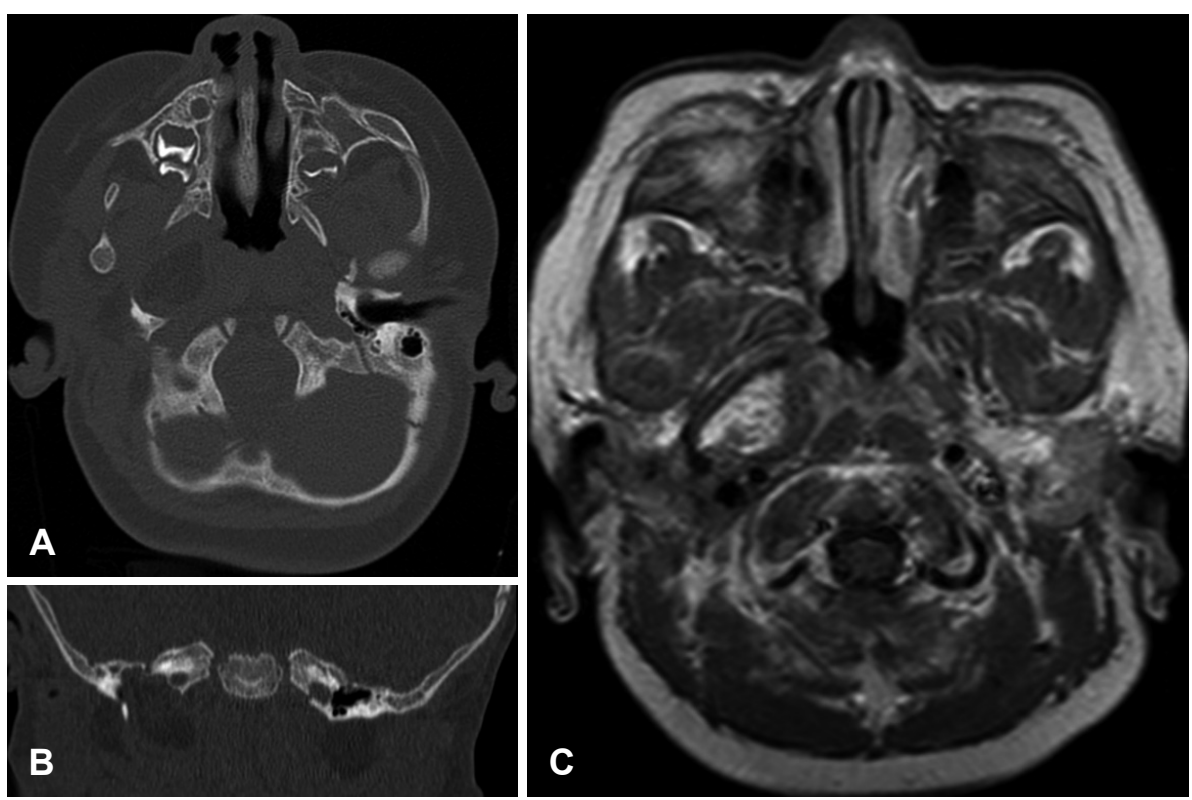

Fig. 3. Gross and histopathological findings of Lipoma. Gross specimen: $3.5 \times 2.3 \mathrm{~cm}$ well encapsulated yellowish mass with ovoid shape (A). A microscopic section of the mass removed from the right middle ear cavity. It is composed of mature adipose tissue cells (B).
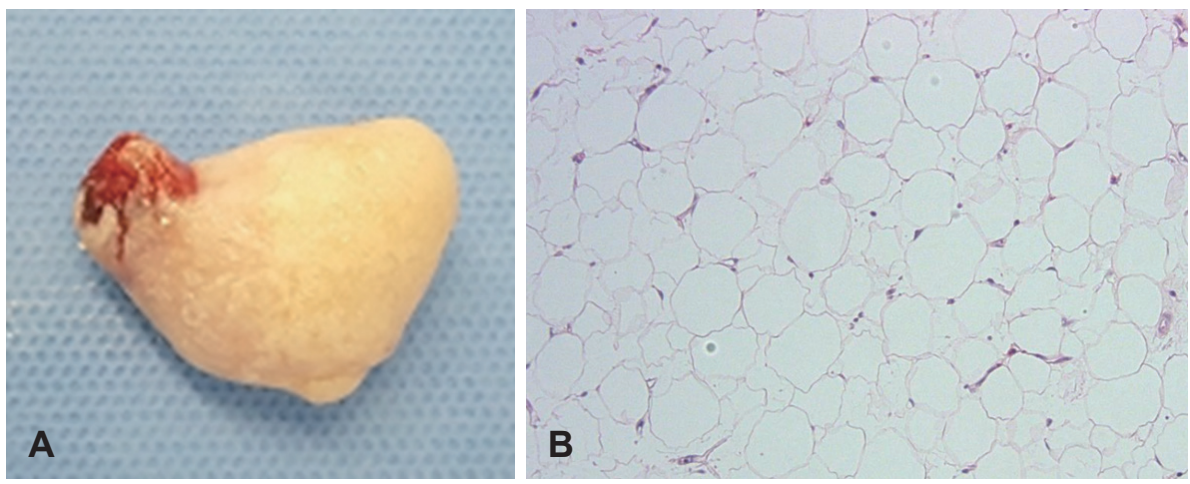

종이 이관구 방향으로 확장됨으로써 이관 폐쇄가 유발되어 발생할 수 있다. 따라서 본 증례와 마찬가지로 삼출성 중이염 이 호전된 이후에 이에 의해 가려졌던 종물이 발견될 수 있 으므로, 검진 시에 유의하여야 한다. 현재까지 발표된 보고에 서도 영·유아에서의 지방종은 삼출성 중이염과 난청으로 인 해 발견된 경우가 많았다(Table 1).

증상과 더불어 고막 내측으로 백색 또는 황색의 종물이 관찰되는 소견을 통해서도 진단에 도움을 받을 수 있으며, 내시경을 통한 비인두 검진이 영상검사 전 병변의 범위를 파 악하는 데 필요하다. 그러나 무엇보다도 $\mathrm{CT}, \mathrm{MRI}$ 를 통한 감 별진단이 중요하다.

선천성 진주종의 경우 소아에서 많이 진단되는 질환이기에 감별이 필요하나 임상적으로 지방종과 진주종을 구분하는 것 이 쉽지 않으며, 진주종으로 임상적 추정 하에 수술적 절제 후 지방종으로 진단된 예에 대한 보고도 있다. ${ }^{3)}$

선천성 진주종은 보통 정상 고막 뒤편 및 이관에 인접한 고 실 앞쪽에 존재하며 후천성 진주종의 경우 상고실에서 발생
하므로 호발 부위에 차이가 있으나, 지방종의 경우 상고실 및 중고실에서 발생한 증례가 모두 보고된 바 있으며 지방종과 진주종 모두 CT에서 저음영으로 관찰되기에 감별에 어려움 이 있다. ${ }^{5)}$ 하지만 지방종의 경우 MRI T1 영상에서 고신호강 도를 보이는 반면 진주종은 $\mathrm{T} 1$ 영상에서 저신호강도를 보이 므로 이를 통해 감별에 도움을 얻을 수 있다. ${ }^{6)}$

콜레스테롤 육아종의 경우 만성 중이염이 있던 환자에서 자기공명영상 검사상 $\mathrm{T} 1$ 에서 고음영, $\mathrm{T} 2$ 에서 고음영으로 나타 나며," 안면신경종의 경우 CT상 안면신경의 확장 소견 및 MRI T1에서 저음영, T2에서 고음영으로 나타난다는 점에서 $\mathrm{T} 1$ 에서 고음영, $\mathrm{T} 2$ 에서 저음영으로 나타나는 지방종과 감별 해낼 수 있다. ${ }^{8)}$

이 외에 감별이 필요한 질환으로는 기형종 및 육종이 있다. 기형종은 다분화능 줄기세포로부터 분화한 외배엽, 중배엽 및 내배엽 조직으로 구성되기에 CT상 불균질한 낭성 또는 고형의 종양 형태로 관찰된다. ${ }^{9}$ 중이 및 유양동에 발생 가능 한 육종으로는 횡문근육종, 배아육종, 연골육종, 골육종 등 


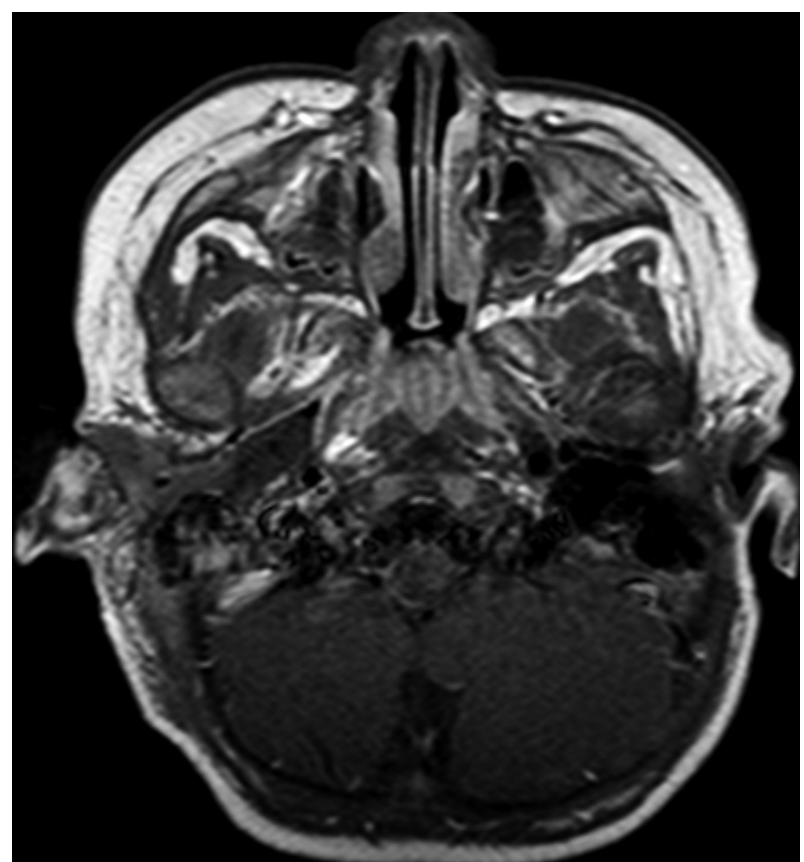

Fig. 4. Post-operative internal auditory canal MRI T1 image which shows no evidence of residual lipoma in the ear.

이 있다. 육종의 경우 진행 속도가 빠르기 때문에 보통 진단단 계에서 안면신경 마비나 다른 신경학적 증상을 동반하고 있 는 경우가 많으며, 영상학적으로 종양 주변 측두골의 파괴 및 경부 림프절로의 전이를 동반하는 경우가 있어 이를 통해 감별해볼 수 있다. ${ }^{10)}$

중이의 신생 종양은 매년 귀 질환을 않는 환자 중 6000명 당 1 명의 비율로 발생하며, 지방종은 흔하지 않지만 중이강 내에 종양이 있을 시 감별해야 할 질환 중 하나로 어린 연령 에서도 발생 가능하기에 중이강 내의 종괴 소견 시 감별진단 에 포함되어야 할 것이다.

지방종의 치료는 수술을 통한 완전 제거가 필요하다. 보고 에 의하면 성인의 경우 안면신경 마비나 호흡곤란 등 다른 합병증이 발생할 가능성이 있으므로 발견되는 즉시 수술적 치료를 고려하는 것이 중요하다.

본 증례에서는 영상학적 소견상 중이 내 종물이 주변의 뼈 를 확장시키면서 이관을 통해 부인두강까지 위치해 있었다. 이에 수술을 계획함에 있어서 고실유양돌기절제술을 통해 종양을 충분히 노출시킴으로써 중이강을 통해 종양을 적출 할 수 있을 것으로 보았다. 또한 종양의 특성상 얇은 피막에 둘러싸여 있기에 주변 조직으로부터의 박리가 어렵지 않을 것으로 예상하였다.

유양동 삭개술과 고실 개방술을 통해 중이강을 노출시키자 삼출액과 종물이 확인되었으며, 침골 제거 후 종물의 일부를 박리해나가며 조금씩 제거를 시행하였다. 제거 과정 중 남은
일부 종양은 중이강 내에서 사라져 비인강에서 발견되어 제거 되었다. 이는 종양의 외부가 매우 미끄럽고, 탄력성이 있기 때 문에 골성 이관부분을 확장시킴으로써 부인강부에 놓여있던 종양이 제거 과정에서 쉽게 이관을 통해 비인강으로 이동한 것으로 생각된다. 따라서 비인강으로 쉽게 빠질 수 있다는 것 을 인지하지 못한다면, 수술 중 종양을 찾지 못하게 될 수도 있을 것이다. 또한 종양이 비인강으로 넘어갔음에도 이를 인 지하지 못한다면, 유·소아에서는 질식과 같은 치명적인 결 과를 가져올 수 있기에 주의가 필요하다. 기존의 보고에서도 비인두까지 확장된 중이강 내의 종물로 인해 호흡곤란을 주 소로 내원한 예가 있었다. ${ }^{2)}$

따라서 중이 내 지방종은 중이강 내 양성 종양에서 감별되 어야 할 질환 중 하나이며, $\mathrm{CT}$ 및 $\mathrm{MRI}$ 를 통해 진단에 도움 을 받을 수 있다. 성인에서는 합병증의 가능성이 높으므로 발견 시 조기에 수술적 치료가 필요하며, 특히 이관 부위에 발생한 지방종인 경우 확장된 이관을 통해 비인강으로 빠져 나갈 수 있으므로 수술 시 주의가 필요하다.

\section{ORCID}

Won Ho Chung https://orcid.org/0000-0001-7157-9935

\section{REFERENCES}

1) Tizian C, Berger A, Vykoupil KF. Malignant degeneration in Madelung's disease (benign lipomatosis of the neck): case report. Br J Plast Surg 1983;36(2):187-9.

2) Stegehuis HR, Guy AM, Anderson KR. Middle-ear lipoma presenting as airways obstruction: case report and review of literature. J Laryngol Otol 1985;99(6):589-91.

3) Abdullah V, Williamson P, Gallimore A, Shah NS. Middle ear lipoma. J Laryngol Otol 1993;107(12):1151-2.

4) Edmonds JL, Woodroof JM, Ator GA. Middle-ear lipoma as a cause of otomastoiditis. J Laryngol Otol 1997;111(12):1162-5.

5) Tachibana T, Nishizaki K, Fujisawa M, Ogawara Y, Matsuyama Y, Abe I, et al. A case of a child with a lipoma of the middle ear and a concomitant chondroma of the external auditory canal. J Case Rep Med 2012;1(1):e1-4.

6) Flint PW, Haughey BH, Lund VJ, Niparko JK, Robbins KT, Thomas JR, et al. Cummings Otolaryngology Head \& Neck Surgery. 5th ed. Philadelphia, PA: Mosby;2010. p.1929.

7) Maroldi R, Farina D, Palvarini L, Marconi A, Gadola E, Mennni K, et al. Computed tomography and magnetic resonance imaging of pathologic conditions of the middle ear. Eur J Radiol 2001;40(2): 78-93.

8) Kirazli T, Oner K, Bilgen C, Ovül I, Midilli R. Facial nerve neuroma: clinical, diagnostic, and surgical features. Skull Base 2004;14(2): 115-20.

9) Flint PW, Haughey BH, Lund VJ, Niparko JK, Robbins KT, Thomas JR, et al. Cummings Otolaryngology Head \& Neck Surgery. Philadelphia, PA: Mosby;2010. p.2527.

10) Flint PW, Haughey BH, Lund VJ, Niparko JK, Robbins KT, Thomas JR, et al. Cummings Otolaryngology Head \& Neck Surgery. Philadelphia, PA: Mosby;2010. p.2840.

11) Karas A, Walner DL, Rabin B, Cham E, Young NM. An unusual pediatric case of bilateral lipoma of the attic and middle ear. Int $\mathrm{J}$ Pediatr Otorhinolaryngol Extra 2011;6(4):206-8. 
12) Chun SS, Kang EG, Bae CH, Lee BD. A case of middle ear lipoma. Korean J Otorhinolaryngol-Head Neck Surg 2009;52(3):273-5.

13) Selesnick SH, Edelstein DR, Parisier SC. Lipoma of the middle ear: an unusual presentation in a 4-year-old child. Otolaryngol Head Neck Surg 1990;102(1):82-4.
14) Aldosari B. Lipoma of the middle ear: an unusual presentation in a 6 year old child. Acta Otorrinolaringol Esp 2014;65(6):381-2.

15) Kasbekar AV, Donnelly N, Axon P. Facial nerve palsy secondary to middle-ear lipoma. J Laryngol Otol 2008;122(6):e14. 